\title{
PENDAMPINGAN GURU DAN MURID GIAT PROGRAM UKS SDN GAMPINGAN 2
}

\author{
Erma Wahyu $\mathrm{M}^{1}$, Nur Aini ${ }^{2}$, Lilis Setyowati ${ }^{3}$, Ollyvia Freeska D.M ${ }^{4}$ \\ Prodi Keperawatan Fakultas Ilmu Kesehatan Univ. Muhammadiyah Malang \\ Email : erma@umm.ac.id
}

\begin{abstract}
ABSTRAK
Sekolah merupakan tempat pembelajaran, tetapi juga sebagai tempat yang dapat mengancam terjadinya penularan penyakit jika tidak dikelola dengan baik. Usia sekolah dasar merupakan usia yang rawan untuk terserang berbagai penyakit. Penyakit yang sering muncul pada anak usia sekolah umumnya terkait dengan Perilaku Hidup Bersih dan Sehat (PHBS). Masalah ini dapat diatasi dengan memaksimalkan fungsi UKS (Usaha Kesehatan Sekolah). Tujuan kegiatan pengabdian adalah sarana meningkatkan wawasan fungsi dari UKS, sebagai sarana yang efektif dalam mensosialisasikan kesehatan ; membentuk PERCIL (Perawat Kecil) sebagai rode model PHBS. Metode kegiatan dengan memberikan pendampingan pengisian raport kesehatan siswa, pengenalan alat-alat UKS dan penyuluhan tentang PHBS (perilaku hidup bersih dan sehat). Kegiatan dilakukan selama 8 bulan pada guru pendamping UKS sejumlah 4 guru dan 20 siswa kader UKS. Setelah pemberian materi, kemudian dilakukan post test dan dipilih 10 siswa berdasarkan nilai post tes tertinggi yang akan dilatih secara intensif untuk menjadi PERCIL (perawat kecil) dan akan mewakili sekolah dalam lomba UKS. Peserta diberikan pre tes dan pos tes oleh pengabdi menggunakan instrumen yang dibuat oleh pengabdi berdasarkan materi yang diberikan. Terjadi peningkatan nilai rata-rata pengetahuan dari 20,65 menjadi 68,85 . Tim juga memberikan bantuan peralatan UKS, poster dan buku raport kesehatan siswa dan buku informasi kesehatan untuk siswa usia usia sekolah. Kegiatan bermanfaat untuk meningkatkan pengetahuan dan ketrampilan Guru dan Kader UKS.
\end{abstract}

Kata Kunci : PHBS, UKS, Kader UKS, Perawat Kecil

\begin{abstract}
A school is a place of learning. However, sometimes school becomes a place that could be the transmission of the disease if it is not properly managed. Primary school age is the age that is prone to various diseases. A disease that often appears in children of school age is generally associated with a Clean and Healthy Lifestyle or Perilaku Hidup Bersih dan Sehat (PHBS). This problem can be solved by maximizing the function of Unit Kesehatan Sekolah (UKS) or School Health Unit. The objectives of this community services were to improve the insight of function of the UKS, as a useful tool in promoting health; forming Perawat Kecil (PERCIL) as a role model of PHBS. The methods of this service were to provide mentoring activities on how to fill in student health report cards, the introduction of tools at the UKS and the education of PHBS. The activities were carried out for eight months in a companion with the teacher of UKS (4 teachers) and 20 student members of UKS. After giving the materials, we did the post-test and selected ten students based on the highest post-test point. The ten selected students trained
\end{abstract}


intensively as a PERCIL and will represent the school in competitions of the UKS. Participants were given a pre-test and post-test by the instruments made by the team of community services based on the material provided. Results: the average value of the knowledge increased from 20.65 to 68.85 . The team also provided the UKS equipment, posters, student health report cards, and school-age students' health information books. These community services had benefits to improve the knowledge and skills of teachers and student members of UKS.

Keywords: Clean and Healthy Lifestyle, student members of UKS, School Health Unit, little nurses

\section{PENDAHULUAN}

Sekolah merupakan tempat pembelajaran, tetapi juga sebagai tempat yang dapat mengancam terjadinya penularan penyakit jika tidak dikelola dengan baik. Usia sekolah dasar merupakan usia yang rawan untuk terserang berbagai penyakit. Penyakit yang sering muncul pada anak usia sekolah umumnya terkait dengan Perilaku Hidup Bersih dan Sehat (PHBS). Aswadi et al (2017), PHBS adalah sekumpulan perilaku yang dipraktikkan atas dasar kesadaran sebagai hasil pembelajaran yang menjadikan seseorang atau keluarga yang dapat menolong diri sendiri dibidang kesehatan dan berperan aktif dalam mewujudkan derajat kesehatan setinggi-tingginya.

Penerapan PHBS dapat dilakukan sejalan dengan kegiatan UKS. UKS adalah program pemerintah untuk meningkatkan pelayanan kesehatan, pendidikan kesehatan, dan pembinaan lingkungan sekolah sehat atau kemampuan hidup sehat bagi warga sekolah. Pentingnya kegiatan UKS ini didukung dengan fakta bahwa di Indonesia kelompok usia sekolah merupakan kelompok usia yang paling besar populasinya. Kelompok umur 5-9 tahun berjumlah hampir 24 juta orang, kelompok umus $10-14$ tahun sebesar lebih dari 22 juta jiwa (Amir, Lesmana, \& Herwansyah, 2018; Ervina, Tahlil, \& Mulyadi, 2019).

Hasil pertemuan awal tim dengan kepala sekolah, guru Pembina UKS (Usaha Kesehatan Sekolah) SDN Gampingan 2, penyakit yang sering dikeluhkan siswa SDN Gampingan 2 antar lain pusing dikarenakan siswa tidak sarapan, diarea, infeksi saluran pernafasan, sakit gigi, gatal - gatal, dan typhoid. UKS SDN Gampingan merupakan perwakilan contoh UKS di Desa Pagak dan akan dimajukan untuk lomba mewakili kecamatan. Tempat, alat seadanya sudah tersedia tetapi pihak sekolah menyampaikan untuk pelaksanaan dan program UKS masih belum berjalan dengan baik dikarenakan kurangnya pengetahuan dan pendampingan dari pihak tenaga kesehatan. Struktur organisasi sering mati suri dikarenakan pengkaderan yang belum maksimal. Saat dilakukan pengkajian pada siswa yang menjadi kader UKS masih banyak yang belum mengerti fungsi dan tugas dari UKS dan bagaimana cara menggunakan alat yang sudah tersedia. 
Permasalahan yang dialami oleh mitra adalah mitra sebenarnya mempunyai potensi untuk mengoptimalkan fungsi UKS, tetapi masih terkendala dengan ketidaktahuan dan bingung tentang program yang akan dilaksanakan, dan cara melakukan pengkaderan sehinggan tidak berhenti saat kader sudah kelas enam. Berdasarkan hasil studi pendahuluan yang telah dilakukan tim penyusun dengan guru UKS dan kepala sekolah SDN Gampingan 2, dapat diidentifikasi dengan permasalahan : kegiatan UKS di SDN Gampingan 2 belum memliki program kesehatan, sehingga kader UKS masih bingung untuk memanfaatkan fasilitas UKS ; pengetahuan siswa SDN Gampingan 2 tentang UKS yang masih rendah ; pihak sekolah menghendaki sistim administrasi secara terstruktur tentang pelaporan, pencatatan, dan perujukan jika ada siswa yang sakit sebagai program UKS ; pihak sekolah belum memiliki buku program kesehatan dan buku kendali kesehatan untuk siswa.

Pihak sekolah menginginkan optimalisasi dari kegiatan dan fungsi UKS, peningkatan program sangat diharapkan oleh kepala sekolah. Pihak sekolah menginginkan terselenggaranya pencatatan, pelaporan dan saat melakukan perujukan kesehatan lebih jelas, sehingga terjadi komunikasi yang baik antar pihak sekolah dan tim kesehatan, serta dengan orang tua siswa, dan adanya bukti nyata dengan adanya pelaporan tersebut. Berdasarkan hasil studi pendahuluan tersebut, tim pengabdi menghendaki untuk mengoptimalkan UKS tingkat sekolah dasar dengan mensosialisasikan dan mengoptimalkan peran UKS, pembentukan perawat kecil (Percil), membuat sitem administrasi pelaporan, pencatatan, dan rujukan yang baik dan benar. Tujuan jangka panjang dari program ini untuk meningkatkan kesehatan dan produktivitas siswa sekolah dasar sehingga lebih peka terhadap kesehatan.

\section{METODE}

dalam pengabdian ini adalah penyuluhan PHBS yang meliputi materi gosok gigi, jajanan sehat, cuci tangan dan perilaku kesehatan ; pendampingan pengukuran status gizi dan penggunaan alat-alat pemeriksaan kesehatan sederhana ; praktik cuci tangan ; praktik gosok gigi ; pengisian buku raport UKS. Kegiatan dilakukan selama 8 bulan pada guru pendamping UKS sejumlah 4 guru dan 20 siswa kader UKS.

Teknis kegiatan dibagi menjadi tahap persiapan, tahap pelaksanaan, dan tahap penilaian. Pada tahap persiapan, tim pengabdi melakukan koordinasi dan perizinan kepada pihak sekolah, menyiapkan bahan dan materi berdasarkan studi pustaka. Pada tahap pelaksanaan, sebelum kegiatan dimulai dilakukan pretest. Kemudian diberikan materi sesuai yang telah disebutkan di atas pada kader UKS dan guru pendamping UKS. Kegiatan dilakukan sebanyak 2 kali. Selanjutnya pada tahap akhir dilakukan post tes dan dipilih 10 siswa berdasarkan nilai post tes tertinggi. Siswa yang terpilih kemudian dilatih secara intensif untuk menjadi PERCIL (perawat kecil) karena mereka akan menjadi role model dan mewakili sekolah 
dalam lomba UKS. Hal ini sesuai dengan permintaan dari pihak sekolah. Pelatihan secara insentif dilakukan sebanyak $2 \mathrm{x}$ yaitu dengan mereview dan penajaman pada materi-materi yang telah diberikan sebelumnya. Tim juga memberikan bantuan peralatan UKS, poster-poster seperti poster jajanan sehat, gosok gigi, status gizi dan cuci tangan serta buku raport kesehatan siswa dan buku informasi kesehatan untuk siswa usia usia sekolah. Buku raport kesehatan diadopsi dari Buku Informasi Kesehatan Peserta Didik SD/MI dari Kementrian Kesehatan
Republik Indonesia (Kemenkes RI, 2019).

\section{HASIL DAN PEMBAHASAN HASIL}

Pengabdian masyarakat ini dilaksanakan di SDN Gampingan 2 Pagak. Lama pelaksanaan kegiatan mulai persiapan sampai dengan pelaporan adalah 8 bulan mulai Februari s/d September 2019. Ada pun hasil sebelum dan setelah kegiatan pengabdian masyarakat adalah sebagai berikut :

Tabel 1. Tingkat Pengetahuan Pre dan Post Sebelum dan Sesudah Kegiatan Pengabdian Masyarakat September 2019 di SDN Gampingan 2 Pagak

\begin{tabular}{|c|c|c|c|c|}
\hline No & Pengetahuan & Pre & Post & \\
\hline 1 & Baik & 0 & $4(20 \%)$ & \multirow{4}{*}{$\begin{array}{l}\text { Mean Pre }=20,65 \\
\mathrm{SD}=2,53 \\
\text { Mean Post }=68,85 \\
\mathrm{SD}=8,37\end{array}$} \\
\hline 2 & Cukup & 0 & $13(65 \%)$ & \\
\hline 3 & Kurang & $20(100 \%)$ & $3(15 \%)$ & \\
\hline & Total & $20(100 \%)$ & $20(100 \%)$ & \\
\hline
\end{tabular}

\section{PEMBAHASAN}

Setelah dilakukan kegiatan pengabdian masyarakat terdapat perubahan pengetahuan. Materimateri yang diujikan, meliputi semua materi PHBS yang diajarkan pada siswa. Siswa yang telah terpilih sebagai PERCIL (perawat kecil), diharapkan menjadi role model sehingga bisa menjadi contoh bagi teman-temanya. Aswadi et al (2017), Kegiatan PHBS di sekolah sangat baik dan bermanfaat. Karena dengan adanya PHBS disekolah dapat melatih siswa - siswi untuk mampuh hidup mandiri dalam menjaga kebersihan lingkungan dan meningkatkan derajat kesehatan.

Pelaksanaan program PHBS di sekolah adalah merupakan suatu keharusan. Karena berdasarkan peraturan MENKES RI No. 226
PHBS harus dilaksanakan di semua tatanan. Terdapat lima tatanan PHBS yaitu PHBS di rumah tangga, PHBS di institusi pendidikan atau sekolah, PHBS di tempat kerja, PHBS di institusi kesehatan dan PHBS di tempat umum (Wulansari, Nurhayati, \& Rahmawati, 2015).

Kegiatan yang dilakukan dalam program pengabdian masyarakat ini tidak hanya berupa penyuluhan, tetapi juga praktik karena dengan praktik akan membuat siswa lebih memahami materi. Becker membagi perilaku sehat menjadi tiga bagian pertama, pengetahuan tentang kesehatan, yaitu apa saja yang diketahui oleh individu tentang cara meningkatkan dan memelihara kesehatan. Kedua, sikap untuk merespon tindakan kesehatan, yaitu penilaian individu atas hal-hal 
yang berhubungan dengan cara memelihara kesehatan. Ketiga, praktik atau tindakan kesehatan yang merupakan tindakan langsung yang terdiri dari semua kegiatan untuk memperoleh kehidupan yang sehat (Notoadmodjo, 2010). Menurut Visi Indonesia sehat 2010, paradigma sehat tidak hanya terdiri dari pelayanan kesehatan yang bermutu, adil tetapi yang tidak kalah pentingnya adalah lingkungan dan perilaku sehat (Lina, 2017). Oleh karena itu, kegiatan PHBS harus ditanamkan seja dini pada siswa sehingga perilaku ini akan menjadi sebuah kebiasaan yang dilaksanakan secara spontan dalam kehidupan sehari-hari mereka.

Hasil post test siswa meningkat lebih dari $90 \%$. Hal ini disebabkan karena pengabdi melakukan pendampingan satu persatu siswa ketika mereka praktik sehingga siswa menjadi lebih faham dengan materi yang disampaikan. Guru UKS juga menjadi lebih paham mengenai materi PHBS, namun dalam kegiatan ini guru tidak diberikan kuisioner. Berdasarkan pada piramida pembelajaran Edgar Dale, dengan melakukan praktik secara langsung maka resistensi pengetahuan di dalam otak $90 \%$ sehingga pemahaman akan suatu pokok bahasan menjadi lebih meningkat. Dalam kegiatan ini, tim juga memberikan bantuan sarana dan prasarana UKS seperti peralatan kesehatan, poster - poster dan buku raport kesehatan siswa. Menurut Wulansari et al (2015), untuk mewujudkan PHBS dibutuhkan tidak hanya dalam bentuk pembelajaran namun pemberian sarana, sikap dan perilaku.

\section{KESIMPULAN \& SARAN}

\section{Kesimpulan}

Kesimpulan yang didapatkan pada pengabdian ini yaitu :

1. Pengetahuan siswa tentang PHBS sebelum penyuluhan adalah 20 orang berada pada kategori kurang, dan setelah kegiatan pengmasy, baik 4 orang, cukup 13 orang dan kurang 3 orang.

2. Pemahaman guru pendamping UKS mengenai PHBS meningkat dan pada siswa maupun guru telah diajarkan cara pengisian raport kesehatan siswa. Selama ini siswa di SDN Gampingan 2 belum memiliki buku raport kesehatan siswa yang seharusnya diperiksa setiap 6 bulan sekali.

\section{Saran}

1. Bagi Sekolah

Menerapkan hasil dari kegiatan pengabdian masyarakat untuk menunjang program UKS serta mengaktifkan kembali program UKS untuk meningkatkan kesehatan siswa.

2. Bagi Siswa Kader UKS

Siswa yang telah terpilih menjadi kader UKS dan mendapatkan pelatihan, diharapkan mampu menerapkan ilmu yang didapat untuk kehidupan mereka sehari hari serta mampu menjadi role model bagi teman-temannya.

\section{DAFTAR PUSTAKA}

Amir, A., Lesmana, O., \& Herwansyah. (2018). Peningkatan Peran Usaha Kesehatan Sekolah (UKS) Tingkat Sekolah Dasar SeKecamatan Telanaipura Kota Jambi. Jurnal Medic, 1(2).

Aswadi, Syahrir, S., Delastara, V., \& Surahmawati. (2017). Perilaku 
Hidup Bersih dan Sehat (PHBS) pada Siswa Siswi SDK Rita Pada Kecamatan Kota Komba Kabupaten Manggarai Timur Propinsi Nusa Tenggara Timur. Public Health Science Journal, 9(2), 187-196.

Ervina, Tahlil, T., \& Mulyadi. (2019). Pelaksanaan Program Usaha Kesehatan Sekolah (UKS) Di Puskesmas. Jurnal Ilmu Keperawatan, 6(2), 11-21.

Lina, H. P. (2017). Perilaku Hidup Bersih Dan Sehat (PHBS) Siswa Di SDN 42 Korong Gadang Kecamatan Kuranji Padang. Jurnal Promkes, 4(1), 92. https://doi.org/10.20473/jpk.v4.i 1.2016.92-103
Notoadmodjo, S. (2010). Ilmu Perilaku Kesehatan. Jakarta: Rineka Cipta.

RI, K. (2019). Buku Informasi Kesehatan Peserta Didik SD/MI.

Wulansari, R. D., Nurhayati, A., \& Rahmawati, Y. (2015). Pengetahuan Guru Sekolah Dasar Tentang Perilaku Hidup Bersih Dan Sehat Sebagai Hasil Pelatihan Dalam Rangka Mewujudkan Sekolah Sehat Di Ciater Subang. Media Pendidikan, Gizi, Dan Kuliner, 4(1), 56-66. 